\title{
SOME DIFFICULTIES IN THE STUDY OF BOTANY IN ONE OF THE SMALL HIGH SCHOOLS.
}

\author{
BY W. W. BAKER, \\ Blue Monnd, Ill.
}

Department Editor's note: Many of the most difficult problems associated with science teaching are found in those small high schools in which the entire curriculum is administered by one, two or sometimes three teachers. The following frank and interesting statement of existing conditions relative to botany in one of these schools is published in the form in which this teacher presents his difficulties. No doubt other teachers in similar schools, as well as those in larger schools, will wish to discuss some of the problems here presented. Such discussions, if brief, will be welcomed to the columns of this magazine.

o. W. C.

The strbject nust be completed in four months. Any honest teacher realizes from his own experience that a mature mind cannot, even fairly master this subject in so short a time, much less can it be done by pupils from thirteen to fifteen years of age. The teacher must either emphasize but a few points and leave much untouched or else take a surface view of the whole. If he omits part, some of his pupils may fail in the county teachers' examination later. Patrons think high school pupils able to pass such examinations and blame the teacher for fail. ures. He does not approve of the skimming process. How much should he attempt to do?

Again, his recitation period is limited to twenty-five minutes. An extra period for laboratory work is hard to find. Most of such work must be done before the class rather than by individual pupils. It is hard to get correct views when one performs the experiment himself, but it is much more so when another performs it. How may the best restilts be obtained?

Each month the county teachers' meeting asks for one of this teacher's Saturdays and the meeting of the teachers of his own section takes another. He must meet his associate teachers weekly and the church and society demand some of his time. It is hard for him to gather material, prepare experiments and microscopical slides enough for the best progress of his class. If you have light upon any of these time phases, let it shine. 
Teachers in general of small high schools may be delighted with the plan of alternation but my limited experience and observation have not made me very enthusiastic in its support. In my school the plan of alternating subjects has thrown sixteen first year pupils, sixteen second year pupils, and one third year pupil together in botany. The difficulty is twofold. The class is too large and the difference in individual ability is too great. Either of these conditions would hinder class progress; combined they demand serious consideration.

The apparatus for science study in the small high school is limited. This school has enough small microscopes for the class but their magnifying power is too low to be of much aid. It has a single large microscope with two objectives but it also is an inferior instrument and one objective must be removed in order to use the other. When you think of a class of thirty-three, getting plant structures first hand by occasional peeps through a single inferior microscope at slides hastily prepared by the teacher himself the impossibility of the task is easily seen.

How muth, then, can be done outside of the text? A small class in our state normal schools under the most favorable conditions consider a "field trip" a "lark," and for a large class it is a "big lark." What term would describe it with thirty-three high school pupils one-half of whom are just out of the eighth grade? Needless to say, "field trips" have not been attempted.

Some of the things that appear to be difficulties in the path of one botany class have been frankly stated. The severest criticism is invited and helpful suggestions are earnestly solicited.

\title{
ON CREATING AN INTEREST IN BOTANY.
}

\author{
By Willard N. Clute, \\ Joliet, Ill.
}

How far is the teacher warranted in departing from the customary methods of teaching a subject in order to interest his pupils in it? This question has presented itself to me in connection with the recent examination of the work of a friend of mine who is a mild sort of iconoclast when it comes to the teaching of botany. He has somewhere acquired the idea that botany ought to be made interesting as well as instructive and educational to the student and looks upon every pupil that leaves 